\title{
A Modern-Day Requirement for Co-ordinated Covert Action
}

\author{
Lessons from the UK's Intelligence History
}

\author{
Rory Cormac, Michael S Goodman and Tom Holman
}

Covert action can be an important weapon in a state's arsenal. It is, however, inherently controversial and risky. Rory Cormac, Michael S Goodman and Tom Holman argue that when considering covert action, Whitehall should look to lessons from the recent past. The UK has long used covert action, and how best to manage and co-ordinate such sensitive activity was for many decades a key preoccupation of its policy-makers and politicians. Given the secrecy involved, these lessons, and the machinery created, have been lost to history. Yet with covert action seemingly now back on the agenda, previous experience and hard-learnt lessons have assumed renewed importance.

The history of Britain's security and intelligence community is long, complicated and, by necessity, secretive. A fundamental feature that has emerged, however, is Whitehall's love of a co-ordinating committee: whether providing all-source intelligence assessment, such as the longstanding Joint Intelligence Committee (JIC), or providing a top-level setting in which to discuss security challenges, such as the National Security Council (NSC). The actual process of co-ordination and discussion undertaken by such committees is often as important as the outcome. It helps provide consensus (if not uniform agreement), ensures that a range of factors or voices are adequately considered, and guarantees the involvement of and interaction between the intelligence and policy communities.

Despite a recent spate of official and authorised histories on British intelligence, important gaps in the literature remain. ${ }^{1}$ Particularly noteworthy among these is Whitehall's approach to covert action. Since 1945, this has revolved around a series of co-ordinating committees which waxed and waned with the vacillations of external and (sometimes more importantly) internal politics. Their existence and activities are only now, slowly, coming to light.

This article argues that how Whitehall co-ordinated covert action in the recent past can offer insight that is useful today, when debates about deniable intervention, proxy warfare, the use of special forces, force multiplication, and responses to so-called 'ambiguous' or 'hybrid' warfare dominate security discourse. Specifically, it argues that useful lessons from the 1960s - when the British government created the Joint Action Committee (JAC) - should be properly integrated into current planning and co-ordinating machinery.

Britain does not have a definition of covert action, although officials have long used the phrase (indeed, it is more than an Americanism that has been assimilated into the English language). For the purposes of this article, however, covert action is defined as intervention in the internal affairs of another state or non-state actor in a plausibly deniable manner. For the UK, this has long involved a broad spectrum of activity ranging from the dissemination of unattributable propaganda on the one hand, to more kinetic special operations (for example, sabotage) on the other. Given Britain's decentralised approach to covert action - which has spanned the Secret Intelligence Service (SIS), GCHQ, Security Service, Foreign Office and the military - some sort of co-ordinating machinery is necessary, especially given the potential risks and controversy associated with such a sensitive form of intervention.

\section{Covert Action Today}


Covert action is on the agenda. The UK wants to play a global leadership role but seemingly lacks the financial, political and military clout to do this as effectively as perhaps desired. ${ }^{2}$ Successive British governments, from that of Clement Attlee in the mid-1940s, have used covert action and special forces as a means of plugging this gap between ambition and ability. The current prime minister, David Cameron, has not been immune to this problem, falling back on similar solutions. Under his premiership, GCHQ has enhanced its 'online covert action' programme, whilst the chief of SIS admitted to targeting Iranian nuclear capabilities. ${ }^{3}$ Covert action was also used in Libya, whilst Cameron has pressed for special forces to be sent to theatres ranging from Mali to Syria, sometimes in a covert role, sometimes in an advisory capacity. ${ }^{4}$ Of course, these are just the instances that have been publicly acknowledged.

Covert action may appeal to the current government for three reasons. First, as mentioned above, it offers a means of reconciling responsibility and capability, role and resources. Second, contemporary conflicts invite covert action. Violent non-state actors cannot always be defeated militarily; they operate in a transnational environment in which the state moves clumsily. In addition, messy modern warfare has blurred the concept of 'victory', and to make matters worse, politicians cannot openly negotiate with terrorist groups either, given the potential political ramifications. This has led to a rise in preventative or 'disruption' operations. ${ }^{5}$ Third, a war-weary public makes it more difficult for governments to use military force, as demonstrated by both Cameron's House of Commons defeat in August 2013 over proposed strikes on Syria and the September 2014 authorisation of strikes against Iraq but not Syria. Polling suggests, however, that the public is more likely to support the use of special forces instead. ${ }^{6}$

Today, covert action is overseen and co-ordinated by the NSC and its attendant machinery, created by Cameron in 2010. This is a particularly important function given the sensitivities and dangers surrounding such activity. ${ }^{7}$ Mistakes can be fatal for a government, whilst leaks can be politically damaging and undermine international relations. 'Blowback', or unintended consequences, can create serious security threats. It is therefore crucial that adequate consideration is given to the management and co-ordination of covert action.

Despite the advent of the NSC, problems in the management of covert action still exist, necessitating an examination of lessons from the recent past. The first problem is the perception of covert action as a 'silver bullet'. The NSC institutionalises co-operation between the most senior policy-makers in the land and military and intelligence chiefs. Its Libya subcommittee met over sixty times during the relatively short 2011 conflict. $^{8}$ Although on the whole a positive development, such regularity and institutionalised contact appears to increase the appeal of covert action. One recent example was the requirement to hunt down Mohammed Emwazi (labelled 'Jihadi John' by the British press), with the prime minister tasking intelligence and security chiefs to 'fix' something after hearing the latest briefing. It is through such direct and immediate contact and tasking that the appeal of covert action is increased. This is potentially dangerous insofar as such actions, if demanded offhand and without detailed discussion, may not necessarily be in line with broader strategic thinking or planning. ${ }^{9}$ This is matched by the absence of NSC mechanisms - according to Alex Allan, a former Joint Intelligence Committee chair - to oversee delivery of these policy options, leaving departments and lead ministers responsible. ${ }^{10}$ This could further hamper interdepartmental co-ordination and scrutiny of covert action, potentially undermining extant strategy further.

This leads on to the second problem: the 'tyranny of the tactical'. The NSC offers senior politicians (who are naturally preoccupied with the short term) much hands-on control. Indeed, Cameron has spoken about the need for action and implementation over longer-term planning within the NSC context. ${ }^{11}$ Advances in real-time communications have given him 
and his colleagues at the senior level much greater say over the tactical aspects of covert action, inter alia, than ever before. Yet tactical developments need to be properly balanced with a more strategic and long-term appraisal. ${ }^{12}$ Many have criticised the NSC for failing to achieve just that, pointing to an absence of policy outcomes on serious security challenges from Ukraine to Syria. A former chief of the defence staff, General David Richards, has stated that 'there is a big difference between talking about strategic issues [at NSC meetings] and being strategic', especially regarding pressing issues such as Libya, the Middle East and Russia. $^{13}$

A third problem stems from the NSC's breadth of responsibility. It might not be appropriate or possible to consider in sufficient detail potential or planned covert action in this forum because the Council has to deal with a swathe of other security issues - broadly covering counter-terrorism, defence and domestic policy issues as well. ${ }^{14}$ Indeed, as noted by one of the designers of the system, Pauline Neville-Jones - the NSC machinery is already overstretched, underpowered and lacking in the ability to follow up on decisions effectively. ${ }^{15}$

Focusing disproportionately on emerging issues or crises, senior policy-makers and officials are unlikely to have the time to debate and scrutinise plans for covert action in sufficiently rigorous detail when faced with myriad other, often more pressing, securityrelated issues. ${ }^{16}$ Yet, given the importance of - and danger inherent to - covert action, detailed scrutiny is required. The embarrassment caused by the failure of an SAS mission in Libya - when an undercover team seeking to make contact with rebel leaders was caught and detained by local militia after noisily landing by helicopter outside of Benghazi - offers an instructive example. Despite the NSC meeting very regularly throughout the Libya intervention, in this instance it clearly neglected to undertake the necessary planning and scrutiny. ${ }^{17}$ Although, for obvious reasons, precise details about contemporary co-ordination machinery are sparse, there is clearly room for improvement.

Broader conceptual factors also hinder British co-ordination of covert action. As the mode of intervention alters, so, too, does the manner in which central command and coordination are enacted and approval is obtained.

In the American system, which has a long history of such activity ${ }^{18}$ special operations are not considered covert action. ${ }^{19}$ The two are very specific and different things. Special operations are an explicitly military activity, defined in Title 10 of the US Code. ${ }^{20}$ Covert action, by contrast, is an act of influence conducted only by the CIA, defined in Title 50 of the US Code. ${ }^{21}$ For the US, this means two parallel forms of command and control. One relating to covert action - designed in the light of the failures of covert action in the $1970 \mathrm{~s},{ }^{22}$ requires an explicit presidential finding. The other - relating to military activity - is subject to a lesser degree of scrutiny. In the same way that the American NSC staff was used to circumvent the approvals process to provide aid to the contras of Nicaragua in the early 1980s, the military approvals route allows the administration to conduct covert action outside of congressional scrutiny.

Yet this distinction has not yet been properly resolved in the UK. This has been for a variety of reasons, including less experience in paramilitary special operations since the Second World War; fewer public inquiries into covert action (such as the 1975 Church Committee in the US); greater levels of government opacity; and a lack of codified definitions. Accordingly, and unlike the US, the UK has continued to conflate special operations and covert action, primarily viewing the former as part of the latter.

This lack of conceptual or definitional clarity can lead - and historically has led - to interdepartmental tensions. Indeed, much of Britain's post-war experience in covert action involved interdepartmental bickering between the Foreign Office and the Chiefs of Staff about who 'owned' such activity during the Cold War. Once it was decided that the Foreign Office would take the lead, turf wars still broke out as diplomats sought to prevent (often 
more hawkish) military voices from encroachment and backseat driving. ${ }^{23}$ Even today, the 'lack of military or defence staff' within the co-ordinating machinery has been criticised by Richards - a complaint familiar to many of his Cold War predecessors. ${ }^{24}$

A further, longstanding problem relates to the equally ill-defined relationship between intelligence, covert action and policy. Indeed, one of the longest-running debates amongst scholars, practitioners and commentators has been whether covert action is part of the intelligence process. ${ }^{25}$ This matters because it has an impact upon the longstanding divide between intelligence and policy; between objective apolitical assessment and political advocacy. For the UK, covert action is not necessarily something conducted by the intelligence community, but it is something in which intelligence, policy and military officials should play (and historically have played) an active role.

All of these factors have created a fluid situation that could result in poorly coordinated covert action. Since 1945, British approaches to covert action have periodically drifted and lacked integration into broader strategic policy. It is therefore useful to look to earlier attempts at interdepartmental co-ordination on covert action, on the basis that the past can raise relevant issues and possibilities which may have since been overlooked or forgotten.

\section{The JAC: A Solution from the Past?}

The Joint Action Committee was created in 1964. Its origins, however, could be found in the late 1950s and the requirements to counter Soviet subversion. Not unlike today, this was an era of proxy warfare, subterfuge and espionage. It was also an era of British decline (albeit marked by a desire to maintain a global role) and of the proliferation of indigenous conflicts in far-flung corners of the globe. Demonstrating parallels with today, there was little serious belief in a conventional or nuclear battle between East and West. Instead, covert action and counter-subversion ("clandestine activities, whether by propaganda or by operations directed against communism or, in the colonies, subversive forms of nationalism ${ }^{26}$ ) were the weapons $d u$ jour. Indeed, a component dedicated to 'Special Political Action', a form of covert action, was created inside SIS in the 1950s with the remit to act 'as the operational element in SIS for the conduct of all clandestine subversive operations in support of overseas policy objectives'. ${ }^{27}$ Despite this climate, Whitehall enjoyed little co-ordination across departments or serious efforts to integrate intelligence into planning of covert action in the early years of the Cold War.

Operating at the most secret and sensitive levels within Whitehall, the Joint Action Committee sought to remedy this. The first meeting of the JAC was called at 'short notice' in early September 1964 and, from the outset, there were serious matters to discuss: unrest in Indonesia and Yemen offered the first opportunities for the new interdepartmental forum to begin work. ${ }^{28}$ Its role was vital because, as the JAC concluded:

\footnotetext{
Political developments and world conditions have led to the occurrence of conflicts in territories abroad without the declaration of war. This had led to requirements being placed... by HMG [Her Majesty's Government] to undertake special operations in these conflicts. In conditions short of Limited or General War it is a political requirement for planning and carrying out special operations that HM Government should be able to deny that it was of intent responsible for a hostile act against another state with which it is formally at peace. The procedures agreed interdepartmentally for satisfying this political requirement are re-stated as they form the basis for planning and execution of all special operations...
}

Increasingly, the JAC focused on those parts of the world where there was a likelihood that the British government would send forces but, from 1966, it also began to consider 'the planning and conduct of special operations in a "pre-emptive" sense where they may be used 
in lieu of intervention by British forces'. These developments and, indeed, their legacy can be considered in four different ways: the relationship between intelligence and covert action; the co-ordination of such activities; their management; and, finally, their scrutiny.

\section{The Intelligence-Covert Action Relationship}

In the 1960s, the JAC helped to resolve numerous problems still prevalent today. It enjoyed a close working relationship with the Joint Intelligence Committee (JIC) and shared its chairman and secretariat, thereby ensuring that a common line was adopted and that intelligence assessments were utilised effectively for planning covert action. This solved an earlier problem, highlighted by Sir Bernard Burrows, the JIC chairman, that 'it was increasingly difficult to arrange the satisfactory processing of matters which involve both secret intelligence and secret action'. The JIC, Burrows lamented, appeared 'to satisfy requirements for current intelligence and longer term assessments, but it has hitherto been prevented by tradition and its terms of reference from considering the secret action which has often flowed from this intelligence and for which the intelligence is often required. ${ }^{29}$

These issues are relevant in the twenty-first century too. The importance of impartial intelligence was strongly highlighted by Lord Butler in his review of the Iraqi WMD fiasco. ${ }^{30}$ Despite various attempts at improving intelligence assessment and dissemination since then, problems remain regarding covert action today - the boundaries between intelligence and policy execution are arguably more blurred than ever before. In a sense this is no bad thing: at the point where intelligence and policy merge there is bound to be a convergence of roles. Yet a modern-day JAC would provide instant relief of another kind. It would provide a forum for the discussion of the specific issue at hand, based on the ideal of collective decisionmaking, of turning intelligence assessments and policy planning into action. As noted earlier, this is difficult in the current system because of the absence of such a subject-specific forum, the NSC and its official machinery being relatively broad actors.

\section{Co-ordination}

JAC membership comprised officials from both the intelligence community and policy departments. Its remit was 'to co-ordinate interdepartmental plans for clandestine operations in areas or situations overseas in which there is or is likely to be intervention by United Kingdom forces'. ${ }^{31}$ This was important because it represented growing liaison between SIS and the military - in other words, 'jointery' - in a system in which the civilians had long held primacy. In the absence of a US-style 'Title 50 vs. Title 10' debate and an explicit legal basis for command of covert action, co-ordination was necessary to soothe potential tensions.

Covert action in this period was the preserve of individual departments: it was, in effect, decentralised. SIS undertook much covert action; but the creation and dissemination of unattributable propaganda was conducted by another actor, the Information Research Department in the Foreign Office (until its disbandment in 1977). Meanwhile, deception operations, which in practice were often connected to covert action, were overseen by the military's Directorate of Forward Plans. SIS, from the late 1950s, also began to work increasingly closely with special forces in what they called 'deniable operations'; $; 2$ and the armed forces maintained an interest in covert action more broadly given that Britain was, as they saw it, fighting a Cold War. ${ }^{33}$ Meanwhile, the anti-colonial nature of many insurgent threats during the period allowed the Colonial Office to claim an interest too. Bilateral links may have existed across departments, but there was little effort to act strategically or to be more systematic in pursuing a cross-Whitehall approach.

Such decentralisation remains the case today. GCHQ has since acquired a role in online effects-based operations and so needs to properly co-ordinate with SIS, the Foreign Office, the Ministry of Defence and special forces. Multiple actors, often with diverging 
visions and goals, require greater co-ordination. This was important in the 1960s but is vital today. On this count, the creation of the NSC machinery was a positive step and goes some way towards achieving such co-ordination, echoing the interdepartmental approach of the JAC. As noted above however, the current system lacks co-ordination in terms of delivery and follow-up. This is especially crucial regarding covert action, the scope of which can easily develop incrementally.

\section{Management}

The JAC also had a managerial function. Over its first few months it discussed not only specific operational matters, but also issues of management. This allowed the most senior people involved in such matters to be briefed on ongoing operations. For instance, one of the committee's first tasks was to consider a paper on the role of the intelligence community in covert action, with a particular focus on how the setting of requirements, planning and the conduct of operations should proceed. Through the JAC, senior officials and the Chiefs of Staff Committee were kept abreast of plans for covert action. Just as importantly, the JAC was used to educate ministers through the circulation of its papers. ${ }^{34}$

Policy-making can be a messy process; the opacity of secret policy only makes it more so. Covert action is a controversial (and potentially seductive) tool, and an issue most often discussed in the context of serious threats to a state's interests - often rendering debate over proposals and counter-proposals emotive, personal and polemic in nature. The JAC provided a useful forum for these discussions. Managing heated debates, often between the military and the diplomats or between local and Whitehall civil servants, the JAC allowed goals and boundaries to be set. It provided an interdepartmental forum, working on the principle of collective responsibility, for the discussion of the extent to which operations would be offensive or defensive; reactive or proactive. These competing ideas, requirements and priorities have to be balanced.

The absence of adequate management creates two problems. The first is gridlock, in which nothing is achieved and proposals are caught up in Whitehall infighting to the detriment of British interests. The second problem is equally detrimental: drift and malaise. These create ad hoc, disconnected and ill-considered covert action or, even worse, circumstances in which nobody knows what is going on. Whitehall has long suffered intermittent periods of drift. In the late 1940s, for instance, key officials scrambled to decipher exactly what they were authorised to do; and prior to the creation of the JAC in the mid-1960s, the lack of co-ordination severely hindered counter-subversion in Yemen and Indonesia where Britain was using bribery, unattributable propaganda, mine laying and SAS ambushes to covertly counter Presidents Nasser and Sukarno, respectively. ${ }^{35}$

This is all the more problematic given that the inherent secrecy of covert action raises the risk that it operates in its own isolated realm. This is dangerous. Disconnection from overt policy is a common cause of covert-action failure. It must be an adjunct, albeit a secret one, to broader political or military strategy. How this is best achieved is subject to debate. Indeed, between the late 1940s and 1960s, Whitehall regularly debated 'horizontal' versus 'vertical' approaches to covert action. ${ }^{36}$ The JAC typified the former in that it was an interdepartmental committee; whereas the latter allowed covert action to be overseen by the sponsoring department (overwhelmingly the Foreign Office) in order to better integrate covert action into the existing policy-making structures and ensure flexibility and speed.

\section{Scrutiny}

Covert action is undeniably a risky means of executing state policy. Plausible deniability provides numerous benefits, including the potential for a light footprint; but should sponsorship become known, covert action could do a great deal of damage to the country (or 
government) in question. It is therefore vital that, if undertaken, covert action is properly scrutinised, involving full consideration of the strengths and weaknesses of an operation alongside its viability, the risk involved and potential fallout or blowback. Moreover, covert action must be connected to broader strategic thinking, thereby preventing an ad hoc (and illconsidered) approach and the dangers of separate or 'rogue' foreign policies. Another key question in this regard is legal scrutiny: the JAC did not cover this aspect in its considerations, but questions of legality have certainly been afforded a more prominent position in recent years, including within the NSC, which is attended by the attorney general as necessary. ${ }^{37}$ Any reincarnation of the JAC would therefore have to take this element into account.

The utility of the JAC lay in the fact that it brought together the intelligence and policy communities to scrutinise proposals. In conjunction with the intelligence community, the JAC helped to determine whether covert action was worth the inevitable risks and whether it would meet its goals. To achieve the latter, an assessment of the balance of power in the respective conflict is necessary. Would aiding a particular rebel group, for example, actually make a difference? Would they win regardless? Would covert support be futile because the rebel group has no chance? Moreover, the JAC, in conjunction with intelligence officials, scrutinised the intended recipient of such covert support. Core questions included their trustworthiness, openness to counter-bribery, resolve to win and links with terror networks. Unintended consequences were also considered. Planners of covert action and the intelligence community assessed the risks of escalation, mission creep, dangers of potential blowback and the impact of an operation becoming public. ${ }^{38}$ This again demonstrates the importance of close relations between intelligence and the planning of covert action. Finally, the JAC also provided an important channel between intelligence, military and policy planners, and senior ministers; discussion and approval were two-way processes.

The same questions were likely asked prior to intervention in Libya in 2011 and when debating Syria in 2013 and again in 2015, especially given failure on the part of the US to create a vetted armed rebel group. The Syrian opposition is deeply fragmented and complex, encompassing links to a variety of extremist and terrorist networks. Cameron has spoken of 70,000 moderate fighters in Syria, ${ }^{39}$ but machinery akin to that of the JAC is vital in determining who these may be and how best to provide covert support. In an age of uncertainty, fluid threats and ever-changing non-state actors, these questions are as important as ever. They are also perhaps even more difficult to answer.

The risk of covert action becoming public is also now greater than ever. More actors tend to be involved today (increasing the risk of leaks), while the digital era challenges the ability of governments to keep secrets. ${ }^{40}$ It is therefore particularly important for planners to consider the consequences of covert action suddenly becoming overt, as happened in Libya in 2011. This needs to be done from the perspective of the domestic population (covert action causes less damage, if leaked, when it is compatible with public opinion) as well as of the target population and other states with an interest in the country in question, both of which could react in a hostile manner. Indeed, international opinion is arguably becoming less tolerant of Western action, covert or otherwise. ${ }^{41}$ Scrutiny, therefore, is essential in today's world.

\section{Conclusions}

From the 1970s the JAC fell into abeyance: the short-lived conflicts which it had been created to tackle had been resolved. Despite a brief resurrection in the early 1980s, it had petered out altogether by the end of the Cold War. ${ }^{42}$ Thereafter, the secrecy in which the JAC had operated ensured that its lessons - and its mere existence - were lost to history. Indeed, 
the system of the 1990s and 2000s was somewhat 'opaque', marked by a lack of clarity about the decision-making processes underpinning policy decisions. ${ }^{43}$

The NSC, and its attendant machinery, is perhaps the closest mechanism Whitehall currently has to the JAC. The purpose of both is to ensure interdepartmental co-ordination. The JAC served to temper more aggressive or ambitious proposals in its day, while the NSC achieved something similar in relation to the Libya intervention. ${ }^{44}$

However, this article argues that more attention is needed specifically on covert action - especially in the current climate in which deniable intervention is tempting yet risky. An important instrument in a state's policy tools, covert action offers certain benefits and should not automatically be discounted. It is, however, an inherently risky and emotive option. Proper co-ordination and management of such activity is therefore vital, especially because certain tensions in the British system have not yet been resolved, owing to history, political culture and bureaucracy. Unlike most other policy tools, it is a practice that consistently escapes critique, whether by academics, journalists or policy-makers. This is for obvious reasons; but its secrecy does not absolve the need for debate or attempts to learn from the past. The JAC is just one example of where an answer was found in the past, but its lessons have been lost to the mists of time.

Rory Cormac is an Assistant Professor of International Relations at the University of Nottingham. He currently holds an AHRC fellowship to research British covert action and is co-author of The Black Door: Spies, Secret Intelligence and British Prime Ministers (William Collins, 2016).

Michael S Goodman is Professor of Intelligence and International Affairs in the Department of War Studies, King's College London. He is currently on secondment to the Cabinet Office completing Volume II of the Official History of the Joint Intelligence Committee (Routledge, forthcoming).

\section{Tom Holman is a PhD candidate at King's College London.}

This article is drawn only from released official records and published sources and the views expressed do not represent those of the British government, nor do they carry the government's endorsement. The authors are grateful to the two anonymous reviewers for their comments on an earlier draft. Rory Cormac would like to thank the AHRC for funding research upon which this article is in part based.

\section{Notes}

\footnotetext{
${ }^{1}$ Christopher Andrew, The Defence of the Realm: The Authorized History of MI5 (London: Allen Lane, 2009); Keith Jeffery, MI6: The History of the Secret Intelligence Service, 1909-1949 (London: Penguin, 2010); Michael S Goodman, The Official History of the Joint Intelligence Committee: Volume I: From the Approach of the Second World War to the Suez Crisis (London: Routledge, 2014).

${ }^{2}$ For discussion see Joint Committee on the National Security Strategy, 'The Next National Security Strategy: First Report of Session 2014-2015', HL 114, HC 749, March 2015; HM Government, Securing Britain in an Age of Uncertainty: The Strategic Defence and Security Review, Cm 7948 (London: The Stationery Office, 2010).

${ }^{3}$ Christopher Hope, 'MI6 Chief Sir John Sawers: We Foiled Iran's Nuclear Weapons Bid', Daily Telegraph, 12 July 2012.

${ }^{4}$ GCHQ, 'Cyber Integration: The Art of the Possible', PowerPoint slides for SigDev Spy Conference, 2012, available via NBC News, 'The Snowden Files: British Spies Used Sex and "Dirty Tricks", 2014, <http://msnbcmedia.msn.com/i/msnbc/sections/news/snowden_cyber_offensive1_nbc_document.pdf>, accessed
} 
3 March 2016; Mark Urban, 'Inside Story of the UK's Secret Mission to Beat Gaddafi', BBC News, 19 January 2012; Matthew D'Ancona, In It Together: The Inside Story of the Coalition Government (Penguin, 2014).

${ }^{5}$ Richard J Aldrich, 'Beyond the Vigilant State: Globalisation and Intelligence', Review of International Studies (Vol. 35, No. 4, October 2009), p. 891; Intelligence and Security Committee of Parliament, Annual Report 2012-2013, HC 547 (London: The Stationery Office, 2013), p. 20; Intelligence and Security Committee of Parliament, Annual Report 2011-2012, Cm 8403 (London: The Stationery Office, 2012), p. 36; Philip H J Davies, MI6 and the Machinery of Spying (London: Frank Cass, 2004), p. 298.

${ }^{6}$ For discussion, see Adrian L Johnson (ed.) Wars in Peace: British Military Operations since 1991 (London: RUSI, 2014). On public opinion of special forces specifically, see Joel Faulkner Rogers, 'Report on British Attitudes to Defence, Security and the Armed Forces', YouGov, 25 October 2014, <https://yougov.co.uk/news/2014/10/25/report-british-attitudes-defence-security-and-arme/>, accessed 3 March 2016.

${ }^{7}$ See Richard J Aldrich, Rory Cormac and Michael S Goodman, Spying on the World: The Declassified Documents of the Joint Intelligence Committee, 1936-2013 (Edinburgh: Edinburgh University Press, 2014), p. 409-16; on Libya, see D'Ancona, In It Together, pp. 159-84.

${ }^{8}$ Peter Ricketts, 'Libya Crisis: National Security Adviser's Review of Central Co-ordination and Lessons

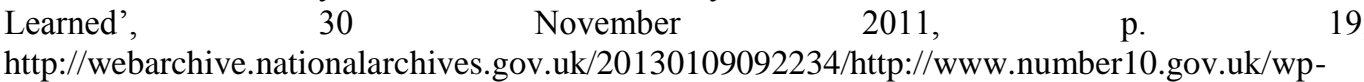
content/uploads/2011/12/Lessons-Learned-30-Nov.pdf >, accessed 3 March 2016.

${ }^{9}$ Mark Hookham, 'SAS Gets "Carte Blanche" on Isis', Sunday Times, 5 July 2015; Richard J Aldrich and Rory Cormac, The Black Door: Spies, Secret Intelligence and British Prime Ministers (London: William Collins, 2016), pp. 482-83.

${ }^{10}$ Joe Devanny, 'Co-ordinating UK Foreign and Security Policy: The National Security Council', RUSI Journal (Vol. 160, No. 6, December 2015), p. 23.

${ }^{11}$ Ibid..

${ }^{12}$ Aldrich and Cormac, The Black Door, p. 460.

${ }^{13}$ Devanny, 'Co-ordinating UK Foreign and Security Policy', p. 22.

14 Joe Devanny and Josh Harris, 'The National Security Council: National Security at the Centre of Government', Institute for Government, London, 2014, p. 29.

${ }^{15}$ Devanny, 'Co-ordinating UK Foreign and Security Policy', p. 23.

${ }^{16}$ Joint Committee on the National Security Strategy, 'National Security Strategy: Evidence from the Prime Minister', HC 1040, 30 January 2014, p. 10, <http://www.parliament.uk/documents/joint-committees/nationalsecurity-strategy/PM\%20session/JCNSS14-01-30TranscriptCameronC.pdf>, accessed 3 March 2016.

${ }^{17}$ Caroline Gammell and Nick Meo, 'Libya: Inside the SAS Operation that Went Wrong', Daily Telegraph, 6 March 2011.

${ }^{18}$ For a good overview, see Sarah-Jane Corke, US Covert Operations and Cold War Strategy: Truman, Secret Warfare and the CIA, 1945-53 (New York, NY: Routledge, 2007); William C Banks, 'Shadow Wars', Journal of National Security Law and Policy (Vol. 5, No. 2, 2012), pp. 315-18; David F Rudgers, 'The Origins of Covert Action', Journal of Contemporary History (Vol. 35, No. 2, April 2000), pp. 249-62.

${ }^{19}$ Jennifer D Kibbe, 'Covert Action and the Pentagon', Intelligence and National Security (Vol. 22, No. 1, March 2007), pp. 57-74.

${ }^{20}$ US Code, Title 10, Section 167, 4(j).

${ }^{21}$ US Code, Title 50, Section 3093(e); US Congress, Intelligence Authorization Act, 105 Stat 444.

${ }^{22}$ Such as the various failed attempts to assassinate foreign leaders. For details, see the 1975 report of the Church Committee, available at <http://www.maryferrell.org/archive/docsets/1014/index.html〉, accessed 3 March 2016.

${ }^{23}$ For more details, see Rory Cormac, Most Unusual Measures: British Approaches to Covert Action since 1945 (Oxford: Oxford University Press, forthcoming).

${ }^{24}$ Devanny, 'Co-ordinating UK Foreign and Security Policy', p. 23.

${ }^{25}$ For instance, see Michael Warner, 'Wanted: A Definition of Intelligence', CIA Studies in Intelligence (Vol. 46, No. 3, 2002).

${ }^{26} \mathrm{~N}$ Brook to A Eden, 28 November 1955. PREM 11/1582.

${ }^{27}$ Minute from J A Drew [Ministry of Defence] to Major General R W McLeod, 9 May 1958. FO 1110/1102. This presumably included the elements of Special Operations Executive that had been absorbed back into SIS in 1945.

${ }^{28}$ On the JAC and Yemen see Clive Jones, Britain and the Yemen Civil War, 1962-1965: Ministers, Mercenaries and Mandarins: Foreign Policy and the Limits of Covert Action (Sussex: Sussex Academic Press, 2010). On the JAC and Indonesia see David Easter, Britain and Confrontation with Indonesia, 1960-66 (London: I B Tauris, 2004). 
${ }^{29}$ The preceding detail is taken from Michael S Goodman, The Official History of the Joint Intelligence Committee, Volume II: 1957-1990 (London: Routledge, forthcoming).

${ }^{30}$ Indeed, it was one of Butler's paramount concerns. Lord Butler et al., 'Review of Intelligence on Weapons of Mass Destruction', HC 898, July 2004.

${ }^{31}$ See Goodman, The Official History of the Joint Intelligence Committee, Volume II: 1957-1990 (London: Routledge, forthcoming).

32 'The MI6 Role and Relationships with Departments of State and the Armed Services in the Conduct of Deniable Operations in Conditions Short of War', 2 November 1964, JA(64)3, FOI Request. 'Deniable' meant, simply, that if discovered it would be possible for Britain to deny involvement and that no evidence would exist linking it to the activities.

${ }^{33}$ See, for instance, FO 1093/375, 'Special Operations', JP(47)118, 17 December 1947.

${ }^{34}$ The preceding detail is taken from Goodman, The Official History of the Joint Intelligence Committee, Volume II.

35 On the former see FO 1093/375, 'Confidential Annex: Meeting of the Chiefs of Staff Held on 10 March, 1948'; on the latter see Goodman, The Official History of the Joint Intelligence Committee, Volume II.

${ }^{36}$ For example, see discussion from 1955 in PREM 11/1582.

${ }^{37}$ Devanny and Harris, 'The National Security Council', p. 18.

${ }^{38}$ See Rory Cormac, 'Coordinating Covert Action: The Case of the Yemen Civil War and the South Arabian Insurgency', Journal of Strategic Studies (Vol. 36, No. 5, 2013), pp. 692-717; Rory Cormac, 'Assessing the Merits of Covert Intervention: Lessons from British Experiences in South Arabia', report for the 'History of British Intelligence and Security' research project, AHRC, 2012.

${ }^{39}$ Frank Gardner, 'Is David Cameron Right About the 70,000 Syrian "Moderates"?', BBC News, 2 December 2015.

${ }^{40}$ Aldrich and Cormac, The Black Door, pp. 485-91.

${ }^{41}$ John Prados, 'The Future of Covert Action', in Loch K Johnson (ed.), Handbook of Intelligence Studies (New York, NY: Routledge, 2007), p. 290.

${ }^{42}$ Philip H J Davies, Intelligence and Government in Britain and the United States, Volume 2: Evolution of the UK Intelligence Community (Santa Barbara, CA: Praeger, 2012), p. 233.

${ }^{43}$ Devanny, 'Co-ordinating UK Foreign and Security Policy', p. 22.

${ }^{44}$ See Aldrich, Cormac and Goodman, Spying on the World, pp. 409-16; on Libya, see D'Ancona, In It Together, pp. 159-84. 